\author{
G. I. Baliuk ${ }^{1}$, Corr. Member of the NAS of Ukraine, \\ Dr. Sc. (Jurid.), Prof., \\ orcid.org/0000-0001-5855-0142, \\ O. P. Kuchynska ${ }^{1}$, Dr. Sc. (Jurid.), Prof., \\ orcid.org/0000-0003-3464-4798, \\ T. G. Kovalchuk ${ }^{1}$, Cand. Sc. (Jurid.), Assoc. Prof., \\ orcid.org/0000-0003-0157-2767, \\ Y. L. Vlasenko ${ }^{1}$, Cand. Sc. (Jurid.), Assoc. Prof., \\ orcid.org/0000-0002-7494-2960, \\ Y.V. Tsyganyuk ${ }^{2}$, Cand. Sc. (Jurid.), \\ orcid.org/0000-0002-8495-3583
}

\title{
CRIMINAL-ENVIRONMENTAL POLICY OF UKRAINE: COMPENSATION FOR DAMAGE CAUSED BY CRIMES AGAINST THE ENVIRONMENT
}

Purpose. To analyze issues of criminal ecological policy of Ukraine, which is one of the ways for human rights protection for individuals who have been harmed as a consequence of committing crimes against the environment; to define the current status of the problem in Ukraine, foreign experience and provide scientifically grounded propositions for current legislation improvement.

Methodology. General and special methods were applied during the investigation: method of formal logical analysis, comparative method, structural approach, sociological, statistical and method of comparative law.

Findings. According to the research, it was established that human rights protection for individuals who have been harmed as a consequence of crimes against environmental safety, requires changes in the legal regulation and in practice of law enforcement in three directions. First, there is a possibility for an individual to be affected only by the infliction of moral damage in environmental crimes. Second, the use of the regulation in The Criminal Procedural Code of Ukraine, according to which the victim cannot be a person who has been inflicted non-pecuniary damage as a legal representative or a certain part of society, has to be treated as erroneous. Third, replacing the notion and concept of "close relatives" and "family members" with "successors" will help to optimize the objectives of criminal proceedings.

Originality. As a result, there have been developed directions of changes in legal regulation and in practice of application of legislation that standardizes human rights protection for individuals who have been damaged in crimes against environmental safety. Also, the criminal procedural legislation's ineffectiveness is established and possible ways of optimizing its provisions are suggested.

Practical value. The practical significance of the results is that they can be used in pre-trial investigations and criminal proceedings on environmental security offenses, by subjects of legislative initiative, scientists, and higher education applicants.

Keywords: criminal ecological policy, environmental safety, victim, environmental crimes, human rights protection, pre-trial investigation, litigation

Introduction. Exacerbation of various aspects of the environmental crisis, environmental degradation, rise in environmental crimes inflicting harm to many countries and regions, including Ukraine, along with increasing consumption of natural resources and negative impacts on the environment, puts the task of finding new measures and mechanisms for environmental protection on the agenda. Many scholars and practitioners, namely, lawyers, economists, politicians, environmentalists and others, are looking for ways to develop and implement special concepts, such as concept of sustainable development, doctrine and practice, actions to address these issues. They should be reflected within complex documents that formulate multi-level goals through political means, envisage certain instruments, which cover, as a rule, various groups of legal, jurisdictional, financial and other measures. In our opinion, such measures should be implemented systematically, coherently and at all levels. The effectiveness of their implementation depends on many factors, including stability of environmental priorities, economic development, interest of the authorities and society in solving environmental problems, quality of legal regulation, established democratic traditions, occurrence of military and ethnic conflicts, development of scientific principles of environmental policies.

Literature review. The mentioned circumstances have already begun to attract attention from scholars and practitioners. Since the 1990s, following 1992 Rio de Janeiro Conference, a number of specific studies have been conducted on the

(C) Baliuk G.I., Kuchynska O.P., Kovalchuk T. G., Vlasenko Y.L., Tsyganyuk Y.V., 2020 goals and principles of environmental policy; a number of respective measures have been developed to optimize its correlation with other types of policies: legal enforcement, energy, food, industrial, transport, and so on. Although these draft proposals are not completely implemented in practice, specific features of the use of environmental instruments are provided to ensure more effective implementation of environmental competences and legal responsibility enforcement. In addition, measures with regard to regional specificities of cities, rural settlements have been developed in the management of waste (including radioactive one). Nowadays, quite a holistic view of the content and structure of environmental policy and its individual directions, its legal and functional principles, tasks and means of achieving them is formed in the legal doctrine, the laws and legal practice.

Unsolved aspects of the problem. At the same time, while some elements of environmental policy are well-known, they are not sufficiently developed as their important constituent components. Meanwhile, their impact on the environmental policy as a whole and the effectiveness of its individual directions is quite significant. In particular, in our view, it also concerns criminal-environmental policy as one of the areas of protection of the rights of citizens who have been harmed by crimes against the environment.

Purpose. The purpose of the article is highlighting the problematic issues of criminal-environmental policy of Ukraine as one of the areas of protection of rights of citizens who are harmed as a result of crimes against the environment, revealing its current state in Ukraine, foreign experience and providing scientifically substantiated proposals for improvement. 
Methods. During the research, general scientific and special methods of research were applied (formal-logical, comparative, system-structural, sociological, statistical ones, method of comparative law).

Results. The history of society has shown that the international community as a whole, including the European Union, has been paying particular attention to combating environmental crimes. Environmental crime entailing scale devastating consequences, along with the prolonged duration of affected ecosystems restoration process, inability to eliminate the consequences of environmental crimes completely in many cases, is the most dangerous kind of crime, since it constitutes a real threat to human existence (Turlova Y.A.). However, the ultima ratio principle is applicable in the criminal law of most democratic states. According to this principle of "minimum interference", the application of criminal law should be the last resort of state impact on the offender, when all other means of civil and administrative law are exhausted or their application is considered to be inappropriate, ineffective or hopeless. The ultima ratio principle can be regarded as an expression of the principle of proportionality, according to which the softest of all appropriate means should be used [1]. However, in the case of serious violations, criminal liability shall be applied regardless of the application of measures from other branches of law. Thus, in order to ensure effective environmental protection, not only the life and health of people must be recognized as the object of crime, but also land, water, air, other differentiated objects subject to criminal protection.

The criminalization of socially dangerous acts occurring in society plays an important role in combating crime. The practice of criminal law development shows that there are many cases where acts that had been not punitive previously, were later recognized as punishable by the legislator. The reasons for such changes in the legislation comprise: a) increasing the public danger of certain actions at a certain time; b) the urgent need to eliminate the gaps in the current legislation; c) changes occurring in society that entail the need to protect their criminal law standards [2]. Such articulation of criminal law tasks required the introduction of specific environmental crime definitions into national law. In the late 1970s, many of the above provisions were deemed as "revolutionary" and met with opposition.

The next step in the formation of environmental criminal law and policy in the area of combating environmental crimes is the decision of 1992 Rio Conference. One of the resolutions adopted at the Conference, which was important for the protection of the environment, stated that the minimum requirement for national law was defining an environmental crime as an act or omission, which would cause significant damage to the environment, violate established environmental standards and create a real and immediate threat to the environment. The subjective element of liability is guilt; in cases of serious misconduct, guilt in the form of negligence is sufficient.

However, if it is proven that the offender has committed an act or omission in the knowledge that they may cause significant harm to the environment, then there is a need to limit the circumstances that eliminate the wrongfulness, mitigate liability and sentence, such as compliance with rules, conditions, permits or administrative orders. The point is that a person who knowingly tolerates significant environmental harm cannot be exposed of liability due to complying with emission standards or other functional administrative requirements. In addition, the resolution states that major environmental crimes should be inserted in national criminal codes. The resolution also touched on the issue of the International Criminal Tribunal, proposing to include crimes against the environment that are of global relevance to its jurisdiction. In particular, crimes against humanity include ecocide that is a criminal impact on the environment which causes irreversible changes, the disappearance of fauna and flora, death of people. Thus, the UN International Law Commission in the Draft Articles on International Responsibility for States [3] has identified serious crime as a serious breach of international obligations that is fundamental to the protection of the environment, in particular, obligations that prohibit mass pollution of the atmosphere or sea.

In 1978, the European Crime Committee of the Council of Europe issued recommendation for lawmakers to recognize a legal entity responsible for environmental crimes, which in 1985 was endorsed by the Seventh United Nations Congress on Crime Prevention and Offender Treatment [4]. The resolution did not provide for the introduction of criminal liability of legal entities itself, but supported this idea, emphasizing that actions that deserve criminal punishment may be committed by both individuals and legal entities, as well as "public bodies". These recommendations have been immediately agreed upon and implemented in the United Kingdom, France, several US states, and other States.

Many authors substantiate the reasonability of this recommendation and consider it to be an optimal mean of maintaining environmental law enforcement at the current stage in connection with the liberalization and deregulation of industrial production [5]. Some specialists state that the introduction of criminal liability of legal entities in the laws of foreign countries was a significant step by legislator in countering the illegal activities of these entities. Thus, the development of the institution of criminal liability of legal entities in these states, which was formed over a considerable historical period of time, allowed determining the grounds for the occurrence of such liability and the list of crimes for which a legal person may be subject to criminal liability, and develop a system of penalties [4].

Thus, the Criminal Code of France dated June 22, 1992 introduced the institution of criminal liability of legal persons with certain reservations, in particular, such as excluding the possibility of criminal liability of legal entities of state and local self-government, if the latter carry out activities that shall not be delegated to other entities; identifying such types of punishment that would exclude the dissolution of public-legal entities, political parties and groups, trade unions; establishing that, along with criminal liability of a legal entity, criminal liability of an individual that is executor or accomplice of the same criminal act is possible; several times increase in the amount of fines imposed on individuals, and so on [4]. In the US, there is also an institution of criminal liability of legal entities. Thus, the Criminal Code (hereinafter referred to as the "CC of Ukraine") of the State of New York provides for the liability of legal persons in paragraph 20, "Criminal Liability of Corporations" [4].

Further, the European legislator has taken more decisive action, in particular, via adopting the Convention on the Protection of the Environment by Criminal Law in Strasbourg on 4 October 1998 [6]. This document has played the most significant role in the unification of criminal justice reform in the area of environmental crime, even in countries that are not party to it. Ukraine signed this Convention on January 24, 2006, although it has not ratified it.

In most cases, the reform of the criminal law was carried out through the introduction of separate chapters on environmental crimes (crimes against the environment), new crime compositions, more severe sanctions, etc. into the respective codes. However, the Environmental Code was adopted in France on September 18, 2000. The law ranks first in the hierarchy of domestic law after the Constitution. The Environmental Code of France consists of General and Special Sections (975 articles), where the General Section (the first book) contains rules on the basic concepts of environmental responsibility, and the another section of the first book regulates the issues of environmental relations, distinction between administrative and criminal liability [7].

On 19 November 2008, the European Parliament and the Council adopted EU Directive 2008/99 on the protection of 
the environment through criminal law [8]. This Directive contained not only a considerable number of novelties that had to be taken into account by the legislators of the EU Member States, but the decisions taken in Strasbourg were substantiated as well. It should be noted that a number of the provisions of the Directive "originate from" the Convention dated 4 October 1998, namely, reproduce its provisions, or transform them into a binding rule and develop new criminal and environmental rules based on their character. It reflects consistency of the position of the European legislator. At the same time, we would like to emphasize that the European Parliament and the Council based their decision on numerous scientific research studies carried out in the EU Member States and not only in them. In our opinion, this fact is essential for Ukraine. It is no secret that in Ukraine, legislative initiatives and decisions are often spontaneous and not substantiated.

In addition, the impact of ECtHR case law on environmental issues also extends to the EU supranational legal system. This applies in particular to obligations to criminalize the most serious environmental violations. The case law of the ECtHR is an example of building a policy in criminal law on the principles that are important in a democratic state, namely, the proportionality and effectiveness of criminal law interventions, which should underpin the law-making process and the practice of law enforcement.

It should be emphasized that the state environmental policy is weak and unsystematic, so large regional enterprises, including metallurgical, chemical and other industries, provide a large number of jobs and pay taxes, but forget about an equally important issue of environmental safety for the protection of life and health of people.

What is the current environmental policy in Ukraine today? Firstly, it is based on environmental and criminal law data; secondly, it is carried out within the framework of environmental and criminal law by various entities of continuous activity. However, contemporary criminal environmental policy in Ukraine is not systematic and complex.

Like other types of legal policy, criminal environmental policy in Ukraine structurally includes a number of elements: a) subjects of development, adoption and implementation of criminal-environmental policy decisions, including the legislative body, executive bodies, local self-government bodies, courts, public associations, interested social groups, and others; b) environmental and criminal law; c) security resources (material, financial and other ones); d) a set of measures for detection, cessation and prevention of environmental crimes. However, as a rule, the elements mentioned above are considered in course of legislation and management system analysis, but not in relation to the tasks of optimizing the criminal environmental policy and improving the effectiveness of its implementation. So, today it is impossible to say that the process of formation of criminal environmental policy in Ukraine in general is complete. In other words, this kind of policy has not formed as a well-established, formalized, unified type of policy yet.

There are many reasons for this situation, among which, in our opinion, the following ones should be distinguished: the unwillingness of society to spend considerable resources on the creation of special structures, whose task is to cease and prevent environmental crimes; rapid spreading and evolution of environmental crime, including the emergence of new types of dangerous unlawful behavior; negligence with regard to the problem of combating environmental crime, which has been observed for many years, lowers its priority in comparison with the declared fight against terrorism, corruption and other types of crime; subjective beliefs of both legislator and politicians, who are often unaware of the important link between environment and economic well-being of the state and citizens, and the degree of reduction of these parameters under the influence of environmental crime and the harm caused to it; lack of proper industry justification and more.
At the same time, it should be emphasized that some components of criminal environmental policy in Ukraine are developing to some extent. This may be confirmed by the development of criminal and criminal procedural legislation (in particular, the CC of Ukraine contains a separate section "Crimes against the Environment").

Besides, environmental crime is characterized by high latency, namely the number of crimes recorded in official national criminal statistics is by hundred and maybe thousand times lower than administrative offenses. In fact, the number of environmental crimes is extremely high, and, therefore, such unlawful behavior is characterized by widespread behavior. New types of unlawful behavior have also emerged as illicit trade in environmental constituents with the simultaneous spread of corrupt criminal behavior, the penetration of organized and professional crime into environmental crime.

In some regions, the illegal use of natural resources has become a livelihood for the local population; changing the modus operandi of environmental crimes and their motivation in obtaining illicit profits and enhancing self-interest; the aggregate damage (environmental and economic ones) of unlawful behavior increases; there are no thorough scientific research studies and jurisprudence reports, work of control and law enforcement bodies in the field of environmental protection.

Further spread of environmental crime poses a threat to the national interests of Ukraine, the well-being and health of its citizens, degrades the image of the State as a whole and, in particular, of its executive authorities.

Pohoretsky M. A., Sergeyeva D. B. and Starenkiy O. S. are convinced that ensuring environmental safety is one of the main conditions for development of Ukraine as a legal, democratic and independent state. In order for its implementation to be effective, our state must promptly implement domestic and foreign policies in the field of protection and environmental protection, ensure a proper process of implementation of the European standards and take into account positive experience of other foreign countries with regard to improving the national environmental legislation, and take all necessary measures for detection, investigation, disclosure and prevention of environmental crimes [9].

According to the report on the results of the state geological control over geological prospecting and rational and effective use of mineral resources in 2018, prepared by the State Service of Geology and Mineral Resources of Ukraine, violations of the law were found during 952 inspections, which is 91.2 percent of the total conducted control measures. Also, in 2018, officials of the Department participated in investigations into 7 criminal cases on illegal mining. Based on the results of the processing, documents withdrawn during the investigative actions, documents were prepared and sent to the initiators of the respective measures. According to the conclusion by A. O. Kyselyov, crimes in the field of mineral resources use in Ukraine are characterized by continuous growth and high latency [10].

According to the results of the state supervision (control) for the first quarter of 2019, 74 materials were sent to law enforcement agencies by the bodies of the State Environmental Inspectorate of Ukraine with signs of criminal offense. Of these, 12 in water resources, incl. surface -3 , marine -0 , of which coastal objects -0 ; ships, seagoing vessels, other vessels -0 , groundwater -9 , floating vehicles -0 ; atmospheric air -4 , incl. stationary objects -4 , of which enterprises, organizations -4 , motor enterprises -0 , mobile vehicles -0 ; land resources -11 ; water fund lands -3 ; mineral resources -4 ; management of waste and chemicals -1 , incl. with industrial waste -1 , incl. with household waste -0 , incl. with pesticides and agrochemicals -0 , incl. with chemicals -0 ; flora -26 , incl. forests -17 ; wildlife -0 , incl. poaching -0 ; fisheries resources -2 , incl. poaching -2 ; nature reserve fund -11 , sources of ionizing radiation -0 , posts of environmental control in the customs territory -0 . 
In addition, in 2019 while proclaiming the annual report of the Commissioner on the Status of Observance and Protection of Human and Citizen's Rights and Freedoms in Ukraine, the Commissioner stated that environmental conditions within the territories not controlled by the Government of Ukraine had deteriorated rapidly. The report stated that on August 27, 2018 in the city of Armiansk, which is located in the Autonomous Republic of Crimea, a pollutant was released at the Titan Investment Plant. As a result, not only residents of Armiansk, but also of Kherson region (settlements of Kalanchak, some settlements of Chaplin and Kalanchak districts) were affected. The Commissioner for Human Rights of the Verkhovna Rada of Ukraine, in order to document the facts of human rights violations, transmitted the information about the event to the UN, OSCE, WHO and the International Committee of the Red Cross, as well as to the Prosecutor's Office of the ARC for information in the Unified Register of Pre-trial Investigations persons involved in violating the environmental rights of citizens in the temporarily occupied territories of Ukraine and threatening their lives. The report also noted that the demographic situation in the occupied territories had deteriorated and identified that the population was dying out.

According to the general data of the State Judicial Administration, in 2017 there were 1204 criminal cases in environmental proceedings against the courts, of which 896 ended up in 772 sentences; in 2018, there were 1,343 criminal cases involving environmental offenses, of which 919 were completed in 778 sentencing cases. At the same time, the dynamics of the number of indictments that came to court in environmental crimes was $11.5 \%$.

In the report on criminal offenses committed at enterprises, institutions, organizations by types of economic activity in January-August 2019, the General Prosecutor's Office of Ukraine classified criminal offenses according to the following categories: agriculture, forestry and fisheries - 1898; mining and quarrying -733 ; manufacturing -1437 ; supply of electricity, gas, steam and air conditioning - 759; water supply; sewage, waste management -780 . Moreover, the sum total of material damage was established in the amount of UAH 80506.35 thousand, of which UAH 22887.63 thousand was provided compensation.

Strengthening criminal liability for environmental crimes is one of the means of effective implementation of criminal environmental policy directions. For example, on April 9, 2015, Ukraine for the first time banned the export of timber, adopting the Law of Ukraine No. 335-VIII "On Amendments to the Law of Ukraine On Features of State Regulation of Entrepreneurship Activities Related to the Implementation and Export of Unprocessed Timber" [11]. In the first edition, the law prohibited the export of raw timber from Ukraine for 10 years.

On September 6, 2018, the Verkhovna Rada of Ukraine adopted the Law of Ukraine No. 2531-VIII "On Preservation of Ukrainian Forests and Prevention of Improper Movement of Raw Timber" [12]. MPs voted for changes to Art. 246 of the $\mathrm{CC}$ of Ukraine on criminal responsibility for the destruction of forests, i.e. it came after causing significant damage to more than UAH 2 million. However, on April 25, 2019 another Law of Ukraine "On Amendments to Certain Legislative Acts of Ukraine on Conservation of the Ukrainian Forests" was adopted, which significantly criminalized it, increased the size and extent of responsibility for violations of forest legislation, by amending the Code of Ukraine on Administrative Offenses and the CC of Ukraine [13].

The sanction under Art. 246 of the CC of Ukraine for illegal felling of trees or shrubs in forests, protective and other forest plantations, transportation, storage, sale of illegally logged trees or shrubs that caused significant damage, provides imposition of fine of one thousand to one thousand five hundred tax-free minimum income or arrest for a term up to six months, or restraint of liberty for a term up to three years, or imprisonment for the same term (Article 246(1) of the CC of Ukraine) [14].

The same actions taken repeatedly or according to prior arrangement by a group of persons are punishable by restraint of liberty for a term of three to five years or imprisonment for the same term (Article 246(2) of the CC of Ukraine). The actions provided for in paragraph 1 of this Article, committed in nature reserves or territories or objects of a nature reserve fund, or in other specially protected forests, shall be punishable by a fine of one thousand five hundred to two thousand non-taxable minimum incomes, or restraint of liberty for a term from three to five years, or imprisonment for the same term (Article 246(3) of the CC of Ukraine). The actions provided for in paragraphs 1, 2 or 3 of this Article shall be punishable by imprisonment for a term of five to seven years, if they caused grave consequences (Article 246(4) of the CC of Ukraine).

Accordingly, significant damage under this Article is considered to be damage exceeding more than twenty times the taxable minimum income of the citizens, or other material damage to the environment in terms of ensuring the effective and proper protection, rational use and reproduction of forests; grave consequences are those that exceed sixty times or more times the non-taxable minimum income.

It should also be noted that in the European Union the Law of Ukraine "On Amendments to Certain Legislative Acts of Ukraine on the Conservation of Ukrainian Forests" has been criticized and was not positively accepted as prohibiting the export of forest is a violation of key trade provisions of the Association Agreement between Ukraine and the EU [15], which prohibit any form of export restrictions.

According to the National Report on the State of the Environment in Ukraine in 2015, Ukraine has a powerful complex of industry, energy, engineering and transport infrastructure. Their objects may be targeted for sabotage and terrorist acts and other criminal activities. It may cause technogenic emergencies that have dangerous socio-economic consequences for Ukraine's national security [16].

Still, the primary concern relates to infliction of harm to the health of citizens as a result of the increase in the number of environmental crimes and their harm (material and moral) to the victims. Health itself is an indicator of equilibrium between a human body and its habitat and has biological stability, with the allowable change of environmental parameters. Therefore, public health as well as hygiene and environmental standards are important criteria for assessing the environmental situation in the country as a whole and in individual regions.

According to WHO data, $80 \%$ of environmental diseases are severe and almost incurable. The number of cancer patients is increasing by $1-4 \%$ every year. It turns out that it is a precise and direct link between structure of the disease and the industries that prevail in this region. It has been revealed that types of oncological diseases also depend on chemical nature of the substance. Yes, asbestos leads to cancer of the lungs, larynx, digestive canal; benzidine for bladder cancer; benzene - to leukemia; vinyl chloride causes cancer of the liver, brain, leukemia; arsenic and its compounds - skin, lung, liver; aromatic amines and solvents - bladder cancer, leukemia; soot, resin, mineral oil - cancer of the skin, lungs, bladder, and others [17].

The summary statistics indicate a high level of threats to the Ukrainian environmental security and the extent of the damage caused by such crimes. Environmental criminal trend is taking new forms and using new tools to streamline its activities. This causes not only its spread, but also, as a result, causes harm, as to specific individuals, legal entities, the state, represented by the authorized bodies, as well as to an unlimited number of persons who are harmed by such crimes, but such persons are not recognized as victims in accordance with the procedure established by the Criminal Procedure Code of Ukraine (hereinafter - the CPC of Ukraine). 
In our view, the legal status of persons harmed by environmental crime should be different from the legal regulation of the rights and obligations of victims of other crimes. The reasoning is the following.

Art. 55(1) of the CPC of Ukraine established that the victim in criminal proceedings shall be a natural person who has been injured by moral, physical or property damage, as well as a legal person who has been injured by property damage.

First, the definition of the concept of the victim, defined in Art. 55(1) of the CPC of Ukraine, despite the clear disclosure of the types of harm caused to an individual, contains problematic aspects restricting its application. In practice, there are no cases of recognition of persons as victims, only on the basis of infliction of moral harm to such persons. There is always a correlation between property - moral or physical - moral. However, in environmental crimes, it is possible to inflict only moral harm to a person. For example, in such crimes as ecocide (Article 441 of the CC of Ukraine, although related to crimes against peace, humanity and international law, but disposition of the article concerns environmental security as an additional mandatory object; crimes that directly pose a risk to life, health and/or the environment, including those provided for in Articles 239, 239-1, 240, 242, 243, 244 of the CC of Ukraine. The norms of the CC of Ukraine also contain a number of other consequences from crimes that may only cause moral harm to individual victims. These are the types of crimes under Article 236 of the CC of Ukraine (consequences in the form of death of people, environmental pollution of large territories or other grave consequences), Article 241 of the CC of Ukraine (air pollution), Article 242 of the $\mathrm{CC}$ of Ukraine (consequences of in the form of pollution of surface or groundwater and aquifers, sources of drinking, healing waters or alteration of their natural properties, or depletion of water sources and created a danger to life, human health or the environment), Art. 243 of the CC of Ukraine (paragraph 1 - consequences in the form of danger to life or health of people or living resources of the sea or could interfere with legal uses of the sea; paragraph 2 - causing death or disease of people, mass destruction of objects of fauna and flora or other grave consequences; paragraph 3 - endangering the life, health or human resources of the sea, or inflicting harm to the treatment and recreation areas or interfere with other legitimate uses of the sea).

In addition, moral harm may be inflicted to the victim not only because of the consequences of the crime, but also due to the way of committing the crime, in particular, the crimes, which are provided for: Art. 245 of the CC of Ukraine comprises destruction or damage to the flora objects in a generally dangerous way; Art. 250 of the CC of Ukraine establishes responsibility for carrying out blasting operations in violation of the rules for the protection of fish stocks; Art. 252 of the CC of Ukraine provides a crime committed by arson or other generally dangerous means. From the above, it is clear that $52 \%$ of environmental crimes, as well as ecocide, may only cause moral harm to the population, either by the way they are committed, or by its consequences.

Hence, it is clear that there is a possibility of causing only moral harm to victim, without property or physical ones, in the crimes against the environment.

Second, Art. 55(4) of the CPC of Ukraine has established a norm according to which the victim may not be a person to whom moral harm was inflicted as a representative of a legal entity or a certain part of society [18]. The provision that the victim cannot be a person to whom moral harm is done as a representative of a certain part of society needs detail. The construction of the norm does not correspond to the legislative practice and correlation with other norms of criminal proceedings. First of all, it is necessary to define the concepts of "representative" and "certain part of society".

"Representative" in criminal procedural norms shall be considered a person who represents the interests of others in the manner and on the grounds provided by the CPC of Ukraine by virtue of law, contract, or on the basis of constituent documents or official duties.

"Certain part of society", according to the co-authors of the CPC of Ukraine, in the context of Art. 55(4) of the CPC of Ukraine, should be understood as a community of people who does not have the status of a legal entity or public entity being united by a common feature or several ones. Accordingly, such a part of society cannot have a representative as a participant in criminal proceedings.

Therefore, "a person who is harmed as a representative of a certain part of society" shall be considered as a representative of a particular part of society that has the same peculiarity (feature) as other persons. Drawing on parallels with the subject of the study, it should be noted that it may be a person who has suffered as a result of either dangerous ways of committing crimes against the environment, or that it could cause his/her death, or endanger the life or health of people. One of the aspects in recognizing such a person as a representative of a particular part of society as a victim of environmental crime is also being considered as a part of society that is conditioned by the territory to which the environmental catastrophe has spread or where generally dangerous means have been applied.

In this aspect, we agree with A. S. Lukomska, who stated that it is necessary to introduce the concept of "victim of environmental crimes" into the scholar glossary, taking into account its material nature and semantic load (functional content). The author argues that it should be used broadly as an individual whose criminal law rights and interests are violated by a crime or socially dangerous, unlawful, criminal offense that violates the environmental law and environmental safety, a person with a guarantee of state protection in accordance with the law; and in a narrow sense, as an individual who died as a result of a negative environmental crime [19]. Many people receive indirect damage precisely in crimes against environmental safety, or indirectly as a result of temporary or permanent environmental changes caused by crime against the environment.

This approach, subject to transformation, may be introduced into national doctrine and implemented into law, especially in the aspect of the analyzed Art. 55(4) of the CPC of Ukraine. Therefore, we consider it appropriate to exclude from the content of Art. 55(4) of the CPC of Ukraine stipulates that the victim may not be a person to whom moral harm was caused as a representative of a certain part of society.

Thirdly, we consider it necessary to introduce amendments to Art. 55(6) (1) of the CPC of Ukraine, in which it is necessary to determine that in case of a criminal offense the death of a person or a person is in a state that makes it impossible to submit a relevant statement, provisions of the paragraphs $1-3$ of this Article apply to the victims' successors (and not to close relatives or members this person's family).

The rationale is as follows. On 16 January 2019, in case No. 439/397/17 the Grand Chamber of the Supreme Court rendered the ruling (hereinafter referred to as the "Ruling") which used the notion of the victim's successor. Thus, paragraph 27 of the Ruling stipulates that Article 55(6) of the CPC of Ukraine provides for so-called succession in criminal proceedings, and paragraph 33 of the Ruling stipulates that during reconciliation only the victim may express his will and not others, who are his/her representatives or successors [20]. This is the first time that the concept has been introduced into the practice of law. It is more appropriate for use, including in crimes against the environment.

The list of persons who are close relatives and family members, as defined in Art. 3(1)(1) of the CPC of Ukraine, contains a large list of persons. In order to ensure the proper performance of criminal proceedings, it should be emphasized that in practice victims should be recognized as successors, as this concept accommodates a wider range of persons, since legal entities may be also included here. 
Conclusions. It is established that the protection of the rights of persons harmed by crimes against environmental safety requires introduction of changes to the legal regulation and practice of enforcement in three directions: 1 ) it is possible to inflict only moral harm to individual in environmental crimes; 2) application of the rules in the CPC of Ukraine according to which the victim may not be a person to whom moral harm was inflicted as a representative of a legal person or a certain part of society on crimes against the environment, is wrong; 3 ) replacement of the concept of close relatives and family members by successors will help to optimize the task of criminal proceedings.

The analysis of the CC of Ukraine regulating criminal liability in environmental crimes has made it possible to conclude that in the analysis of the objective side of individual crimes $(52 \%$ of the total number of crimes against environmental safety), a person may also be inflicted only moral harm. The co-authors adhere to the position that it is not compulsory to link that moral harm as to mere result of property or physical harm; it may be a separate form of harm as a basis for bringing criminal proceedings as a victim.

In course of a detailed study of the rules under of Art. 55(4) of the CPC of Ukraine, one of which found that the victim could not be a person to whom moral harm was inflicted as to a representative of certain part of society, the authors concluded it is inconsistent with the factual circumstances arising in the commission of crimes against environmental safety. These rules should be excluded from the content of Art. 55(4) of the CPC of Ukraine.

Taking into account the quasi-subjectivity of certain relationships or persons who have found their place in legal relationships governed by applicable law, the co-authors concluded that the use of the term "successors" instead of "close relatives and family members" is more appropriate in the norms of Art. 55(6) of the CPC of Ukraine.

\section{References.}

1. Khylhendorf, Je. (2012). Punitive legislation and criminal law doctrine. Issues of Russian and International Law, 1, 111-141.

2. Schulga, A. M. (2013). Criminal protection of land from pollution or damage: monograph. Kharkiv: Kharkiv National University of Internal Affairs.

3. Draft articles on the responsibility of States for internationally wrongful acts 2001. Report of the International Law Commission on the work of its fifty-third session (A/56/10) (2001). Retrieved from https://legal.un.org/ilc/publications/yearbooks/russian/ ilc 2001 v2 p2.pdf.

4. Hryshchuk, V. K., \& Pasieka, O. F. (2013). Criminal liability of legal entities: comparative legal research: monograph. Lviv: State University of Internal Affairs.

5. Shumilo, O. (2014). Criminal liability of legal entities for environmental crimes. National Law Journal, 185, 181-186.

6. The Convention on the Protection of the Environment by Criminal Law of 04.11.1998/Council of Europe (ETS N 172) (n.d.). Retrieved from https://zakon.rada.gov.ua/laws/show/994 560. 7. Panchenko, O. V., \& Proskura, T. B. (2017). Codification of environmental legislation: world experience and Ukrainian perspectives. Young Scientist, 3, 549-554.

8. Directive No 2008/99/EU of the European Parliament and of the Council on the protection of the environment through criminal law /2008/99/EU (n.d.). Retrieved from: https: //zakon.rada. gov.ua/laws/main/994 a63.

9. Pohoretskyi, M.A., Serhieieva, D. B., \& Starenkyi, O.S. (2019). Expert's findings in criminal proceedings on environmental crimes. Naukovyi Visnyk Natsionalnoho Hirnychoho Universytetu, (1), 155-163. https://doi.org/10.29202/nvn$\mathrm{gu} / 2019-1 / 16$.

10. Kyselov, A. O. (2019). Combating illegal amber mining: peculiarities of conflict resolution. Naukovyi Visnyk Natsionalnoho Hirnychoho Universytetu, (2), 146-152. https://doi. org/10.29202/nvngu/2019-2/19.
11. Law of Ukraine "On Amendments to the Law of Ukraine" On Peculiarities of State Regulation of the Activity of Entities of Entrepreneurship Activities Related to the Implementation and Export of Timber", 2015, (2015, April 9). Vidomosti of the Verkhovna Rada, 31, 29. Retrieved from https://zakon.rada. gov.ua/laws/show/2860-15.

12. Law of Ukraine "On Preservation of Ukrainian Forests and Prevention of Improper Movement of Raw Timber», 2018, (2018, September 6). Vidomosti of the Verkhovna Rada, 42, 327. Retrieved from https:/https://zakon.rada.gov.ua/ laws/show/2531-19.

13. Law of Ukraine "On Amendments to Certain Legislative Acts of Ukraine on the Conservation of Ukrainian Forests", 2019, (2019, April 25). Vidomosti of the Verkhovna Rada, 22, 83. Retrieved from https://zakon.rada.gov.ua/laws/show/2708-19. 14. Criminal Code of Ukraine, 2001, (2001, April 05). (Edited by 10/18/2019). Vidomosti of the Verkhovna Rada, 25-26, 131. Retrieved from https://zakon.rada.gov.ua/laws/show/234114.

15. Association Agreement between Ukraine, on the one hand, and the European Union, the European Atomic Energy Community, and their Member States, on the other. The agreement was ratified by the Law of September 16, 2014 (2014). Retrieved from https://zakon.rada.gov.ua/laws/show/984_011.

16. Ministry of Ecology and Natural Resources of Ukraine, FOP Grin D. S. (2017). National Report on the State of the Environment in Ukraine in 2015. Retrieved from https://menr. gov.ua/news/31768.html.

17. Khylko, M. I. (2018). Biosphere and human health. Philosophical Sciences. The collection of scientific works "Gilea: the scientific bulletin", 133, 140-143.

18. Criminal Procedure Code of Ukraine, 2012 (2012, April 13). Retrieved from https://zakon.rada.gov.ua/laws/show/465117\#n801.

19. Lukomskaya, A. S. (2017). Victim of environmental crime in Russian criminal proceedings: monograph. Institute for Computer Research.

20. Judgment of the Grand Chamber of the Supreme Court in Case 439/397/17, 2019, (2019, January 16)). Retrieved from http://reyestr.court.gov.ua/Review/79298600.

\section{Кримінально-екологічна політика України: відшкодування шкоди внаслідок злочинів проти довкілля}

\section{Г. І. Балюк ${ }^{1}$, О. П. Кучинська ${ }^{1}$, Т. Г. Ковальчук Ю. Л. Власенко ${ }^{1}$, Ю. В. Циганюк 2}

1 - Київський національний університет імені Тараса Шевченка, м. Київ, Україна, e-mail: 2000_oksana@ukr.net 2 - Хмельницький інститут Міжрегіональної Академії управління персоналом, м. Хмельницький, Україна

Мета. Висвітлити проблемні питання кримінальноекологічної політика України як одного з напрямів захисту прав громадян, яким завдано шкоду внаслідок вчинення злочинів проти довкілля, охарактеризувати сучасний стан в Україні, зарубіжний досвід і надати науковообгрунтовані пропозиції вдосконалення чинного законодавства.

Методика. Під час дослідження застосовувались загальнонаукові та спеціальні методи дослідження: формально-логічний, компаративістський, системно-структурний, соціологічний, статистичний, метод порівняльного правознавства.

Результати. Встановлено, що захист прав осіб, які зазнали шкоди у злочинах проти екологічної безпеки, потребує змін у правовому регулюванні та практиці правозастосування у трьох напрямах. По-перше, в екологічних злочинах можливе завдання фізичній особі також лише 
моральної шкоди. По-друге, використання в нормах КПК України положення, згідно якого потерпілим не може бути особа, якій моральна шкода завдана як представнику юридичної особи чи певної частини суспільства, щодо злочинів проти довкілля, є помилковим. Потретє, заміна поняття «близькі родичі» та «члени сім'ї» на «правонаступники» допоможе оптимізувати завдання кримінального провадження.

Наукова новизна. Розроблені напрями змін правового регулювання та практики застосування законодавства, що регулює захист прав осіб, які зазнали шкоди у злочинах проти екологічної безпеки. Також встановлені недоліки кримінально-процесуального законодавства й запропоновані можливі шляхи оптимізації його положень.

Практична значимість. Практична значимість отриманих результатів полягає в тому, що вони можуть бути використані під час досудового розслідування й судового розгляду кримінальних проваджень щодо злочинів у сфері екологічної безпеки, суб'єктами законодавчої ініціативи, науковцями, здобувачами вищої освіти.

Ключові слова: кримінально-екологічна політика, екологічна безпека, потерпілий, злочини проти довкілля, захист прав осіб, досудове розслідування, судовий розгляд

\section{Криминально-экологическая политика Украины: возмещение вреда в результате преступлений против окружающей среды}

\section{Г. И. Балюк ${ }^{1}$ О. П. Кучинская ${ }^{1}$, Т. Г. Ковальчук ${ }^{1}$, Ю. Л. Власенко ${ }^{1}$ Ю. В. Циганюк ${ }^{2}$}

1 - Киевский национальный университет имени Тараса Шевченко, г. Киев, Украина, e-mail:2000_oksana@ukr.net 2 - Хмельницкий институт Межрегиональной Академии управления персоналом, г. Хмельницкий, Украина

Цель. Осветить проблемные вопросы уголовно-экологической политики Украины как одного из направлений защиты прав граждан, которым причинен ущерб в результате совершения преступлений против окружающей среды, охарактеризовать современное состояние в Украине, зарубежный опыт и предоставить научно обо- снованные предложения усовершенствования действующего законодательства.

Методика. Во время исследования использовались общенаучные и специальные методы исследования: формально-логический, компаративистский, системноструктурный, социологический, статистический, метод сравнительного правоведения.

Результаты. Установлено, что защита прав лиц, которым был причинен вред преступлениями против экологической безопасности требует изменений в правовом регулировании и практике правоприменения в трех направлениях. Во-первых, в экологических преступлениях возможно причинение физическому лицу только морального вреда. Во-вторых, использование в нормах УПК Украины положения, согласно которому потерпевшим не может быть лицо, которому моральный вред причинен как представителю юридического лица или определенной части общества, о преступлениях против окружающей среды, является ошибочным. В-третьих, замена понятия «близкие родственники» и «члены семьи» на «правопреемники» поможет оптимизировать задачи уголовного производства.

Научная новизна. Разработаны направления изменений правового регулирования и практики применения законодательства, регулирующего защиту прав лиц, понесших ущерб в преступлениях против экологической безопасности. Также установлены недостатки уголовнопроцессуального законодательства и предложены возможные пути оптимизации его положений.

Практическая значимость. Практическое значение полученных результатов заключается в том, что они могут быть использованы во время досудебного расследования и судебного рассмотрения уголовных производств по преступлениям в сфере экологической безопасности, субъектами законодательной инициативы, учеными, соискателями высшего образования.

Ключевые слова: уголовно-экологическая политика, экологическая безопасность, потерпевший, преступления против окружающей среды, защита прав лиц, досудебное расследование, судебное разбирательство

Recommended for publication by N. R. Malysheva, Doctor of Juridical Science. The manuscript was submitted 19.09.19. 